\title{
THE LIVE GOAT RITUAL IN LEVITICUS 16
}

\author{
Yaw Adu-Gyamfi \\ Department of Religion and Theology \\ University of the Western Cape
}

\begin{abstract}
The live goat ritual in Leviticus 16 has, for many decades, attracted debate in biblical scholarship. However, the main focus has often been on the identity of Azazel. This article examines some aspects of the live goat ritual in Leviticus 16: (1) the use of two hands rather than the usual one hand laid over the head of the goat; (2) the content of the confession over the goat; (3) the purpose of the rite; (4) whether the ritual is a sacrifice or something else; and (5) the significance of the ritual. I contend that the two hands used are representational, that the ritual is a unique sacrifice, and that the ritual symbolized a complete eradication of sin from the community.
\end{abstract}

Key words: Atonement; Live Goat; Leviticus 16; Ritual

\section{Introduction}

Leviticus 16 records the annual purification rituals of ancient Israel. ${ }^{1}$ Among the various rituals were those of dead and live goats. While the ritual of the dead goat has not attracted much debate, that of the live goat has attracted much scholarly attention. In general, the aspect of this ritual on which scholars have spent time and space is the term Azazel

I have used 'Israel' to designate the ancient Israel, not the ten northern tribes. I use the term to assume that the ritual under investigation is much more ancient than is often thought. By the $19^{\text {th }}$ century Leviticus was seen to consist of priestly material (P), one of the four postulated sources of the Pentateuch (J, E, D and P). Within the P source, Leviticus 17-26 was identified as a separate block of material, the so-called Holiness Code $(\mathrm{H})$ towards the end of the century (for a summary see Christophe Nihan, "From Priestly Torah to Pentateuch: A Study in the Composition of the Book of Leviticus" (DTh diss., University of Lausanne, 2005:1-4). Nineteenth century scholarship identified $\mathrm{J}$ and $\mathrm{E}$ as the earliest sources (early monarchic period), followed by D (seventh century BCE) and then P (exilic-postexilic period) (For detailed treatment, see Julius Wellhausen, Prolegomena to the History of Israel [Atlanta: Scholars Press, 1994]). Once H was identified as a separate entity, it was generally seen to precede P (see e.g., Nihan From Priestly to the Pentateuch, p. 4). The majority of scholars would date $\mathrm{P}$ and also $\mathrm{H}$ to the exilic-post-exilic time, even though some others would date the origins of $\mathrm{P}$ even to the premonarchial period, and $\mathrm{H}$ to about the $8^{\text {th }}-6^{\text {th }}$ centuries (see e.g., Jacob Milgrom, Leviticus, 3 vols, AB [New York: Doubleday, 1991-2001]; Moshe Weinfeld, The Place of the Law in the Religion of Ancient Israel [Leiden: Brill, 2004]). To determine the provenance of Leviticus 16 has strong links with determining the context of Leviticus 16 and its sources in the wider context of Leviticus. Similarly, to determine the provenance of Leviticus has links with determining the context of Leviticus in its sources in the wider context of the Pentateuch and Joshua and Judges-2 Kings. I am aware that naturally, it is eventually impossible to prove a pre-Hellenistic origin for the biblical materials, for our earliest known biblical manuscripts date to the second century BCE (Qumran). However, the ancient Near Eastern evidence we now have available as a result of cumulative excavations and publications since the latter half of the $19^{\text {th }}$ century indicate the possibility of an earlier origin of concepts that relate to P in Leviticus. Yitzhaq Feder's recent study has compared the sin offering (חט:א) with Hurro-Hittite blood (zurki) rituals that derive from the late Bronze Age (Blood Expiation in Hittite and Biblical Ritual: Origins, Context and Meaning [Atlanta: Society of Biblical Literature, 2011]). The comparison demonstrates a number of similarities with the biblical ritual including Leviticus 4-5, 8, 12, 14 and 16. For example, the Hittite ideas and ritual procedures of purification by means of two birds, where the first bird is used for the blood rite, and the second is apparently offered to infernal deities and thus transports evil to the underworld, offers a parallel to the rituals of the two goats in Leviticus 16, and shows the antiquity of two he-goats rituals in Leviticus 16. Weinfeld refers to a Hittite ritual that offers an even more direct parallel to the live-goat ritual in Leviticus 16 (Place of the Law, 49-50). 
(עז), ${ }^{2}$ which occurs only in Lev 16:8, 10 (x2), and 26 and on the occurrence of similar rituals in other ancient Near East cultures to reveal its origin and purpose. Surprisingly, scholars have not attended much to other aspects of the ritual: (1) The hand-laying of the priest's two hands instead of one hand; (2) the content of the confession that accompanied the laying on of the two hands; (3) while the dead-goat ritual is accepted as a sacrifice to Yahweh, it is not clear what the live-goat ritual is; and (4) the significance of the ritual. The aim of thisarticle, therefore, is to investigate the above-mentioned aspects of the ritual that have received less scholarly attention.

\section{Laying of Two Hands}

In this particular ritual the high priest lays both hands upon the head of the goat. In purification offerings made throughout the year, a single hand is laid on the head of the animal (see e.g., Lev 1:4; 3:2, 8, 13; 4:4, 15, 24, 29, 33). J Milgrom underscores the difference between the sacrificial use of one hand, expressing identification with the offerer, and the use of two hands for transferral in non-sacrificial contexts. ${ }^{3}$ On the contrary, N Kiuchi thinks that the hand-leaning does not warrant an automatic transfer of $\sin$. He agrees that the purpose of the hand-leaning is to transfer the guilt of the Israelites to the live-goat. He intimates that the act itself does not necessarily symbolize the 'transference of guilt' mentioned in v. $21 \mathrm{~b} \alpha$. He argues the possibility that the hand-leaning in Lev 16:21 also symbolizes the notion of 'substitution' as in Lev 1:4. He, however, acknowledges that since on the Day of Atonement the high priest lays his hands on behalf of the Israelites, the question remains in what sense the substitution is envisaged. ${ }^{4}$ However, the difference between using one hand or both hands is unlikely to convey such disparate meanings, but rather suggests a difference in degree. ${ }^{5}$

WC Kaiser, in order to support a substitutionary interpretation of atonement, argues that in the original consonantal text, ידו in Lev 1:4 and elsewhere could have represented a dual form (ידירוּ ), referring to two hands, even though the MT invariably vocalizes this form as singular (דירז $\left.{ }_{\mathrm{T}}\right){ }^{6}$ Kaiser, however, does not give sufficient weight to the fact that only in Lev 16:21 does the text unambiguously specify the placement of two hands on the live goat by using the numeral שֶׁ, 'two.' The live-goat ritual is unique in its requiring that two hands be laid on the goat rather than one. The need to place two hands on the live-goat may well be quantitative. Here, the identification is greater because it involved the transfer of the collective moral faults of all Israelites. ${ }^{7} \mathrm{~N}$ Snaith interpreted the laying of two hands from a different perspective: "to make doubly sure of the transference of the $\sin { }^{\circ} .8$ Nonetheless,

2 See Aron Pinker, "A Goat to Go to Azazel” in Journal of Hebrew Scriptures 7 (2007) for the various views of the term Azazel; See also Robert Helm, “Azazel in Early Jewish Tradition,” AUSS 32, 1994:217-226.

3 Jacob Milgrom, "Sacrifices and Offerings, OT," in IDB Sup. Nashville: Abingdon Press, 1976, 765; idem, Leviticus 1-16. New York: Doubleday, 1991:1041.

4 Nobuyoshi Kiuchi, The Purification Offering in the Priestly Literature: Its Meaning and Function (JSOT Supp. 56; Sheffield: JSOT Press, 1987:118-19.

5 Noam Zohar, "Repentance and Purification: The Significance and Semantics of 5ט JBL 107, 1988:613, n. 24.

$6 \quad$ Walter C Kaiser, “The Book of Leviticus,” NIB 1:1011.

7 Ray Gane, Cult and Character: Purification Offerings, Day of Atonement, and Theodicy. Winona Lake, Indiana: Eisenbrauns, 2005:58-59.

$8 \quad$ Norman Snaith, Leviticus and Numbers (new ed.), London: Nelson, 1967:115. 
qualitatively, the placing of two hands differs from the one hand gesture: the placing of two hands on the live goat does not signal the transfer of the ownership of the animal; this has already been done through the manipulating of lots (v. 5). Thus, the transfer here only moves the sins of the people to the goat. Another possibility may well be representative: one hand for Aaron and his family and the other for the people. ${ }^{9}$

\section{Confession Accompanying Hand-laying}

The text clearly indicates that the laying of two hands upon the live goat is accompanied by a simultaneous confession (v. 21). However, the text does not provide what was recited in the confession. Strangely, the Mishna, a much later text, has suggested the following as the recitation of the confession made upon the live-goat:

O Lord, your people, the house of Israel, have committed iniquity, transgressed, and sinned before you. O, by the Lord . . . grant atonement, I pray, for the iniquities, and transgressions and sins that your people the house of Israel have committed and transgressed before you; as it is written in the Torah of your servant Moses: 'For on this day shall atonement be made for you to purify you of all your sins; thus you shall become pure before the Lord' (m. Yoma 6:2). ${ }^{10}$

We do not know the source(s) of the Mishna's recitation. But whatever the recitation in the confession the fact remains that the high priest with both hands on the live-goat prayed to God for the sins of the people. The day was set up to purify the people of their sins to stand before God pure.

$\mathrm{H}$ Gese posits that it was the confession alone that accomplished the transfer of the sins of the people upon the live goat; ${ }^{11}$ in which case the hand-laying does not connote transfer. Unfortunately, Gese does not explain what the hand-laying then signifies. But as JH Kurt notes, the hand-laying and the simultaneous confession indicate that "here, and nowhere else, the imposition of hands was to be regarded as a laying on of $\sin$ ". ${ }^{2}$ So, the handlaying and confession together accomplished one purpose: the hand-laying designates the destination of the confessed sins. Thus, the hand-laying is the vehicle that conveys the verbal pronouncement of the sins of the people onto the head of the goat. ${ }^{13}$ Therefore, the transfer to the live goat is not achieved by hand-laying; the high priest's confession is necessary for this. ${ }^{14}$

\section{The Purpose of the Live-Goat Rite}

The purpose of the live-goat rite is first introduced in v. 10: “...to make atonement upon it

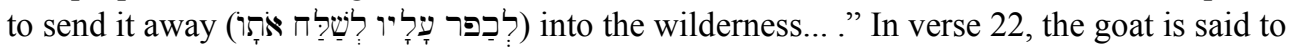

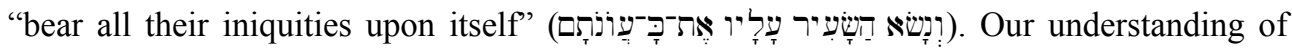

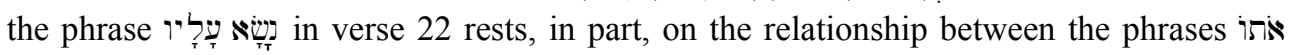

\footnotetext{
Christian Ginsburg, Leviticus. Grand Rapids: Zondervan, 1961:155.

Cited in Milgrom, Leviticus 1-16, 1043.

Hartmut Gese, Essays on Biblical Theology. Trans. Keith Crim; Minneapolis: Augsburg, 1981:105-106.

2 Johann H Kurtz, Sacrificial Worship of the Old Testament. Trans. James Martin; Minneapolis:

Klock \& Klock, 1980:99.

13 Milgrom, Leviticus 1-16, 1043.

14 Cf. Kiuchi, Purification Offering, 118.
} 


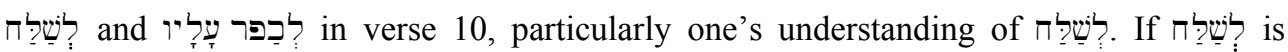
understood to act as a purpose clause it would imply that atonement is made upon the goat so that it may then be sent into the wilderness. This implies that the atonement rite is complete before the goat is sent off; thus, the rite consists only of confessing and placing

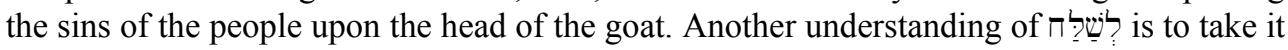
as explicative of לכבפר עָרזיו, which will mean that atonement is made with the goat by sending it into the wilderness. ${ }^{15}$ Thus, the atonement rite does not consist only of confessing the sins and placing them upon the head of the goat, but also in sending the goat into the wilderness.

M Maimonides explains that the live goat was sent to the wilderness to serve as an atonement for all serious transgressions more than any other sin-offering of the congregation. He adds that because it carries off all sins, it was not accepted as an ordinary sacrifice to be slaughtered, burnt, or even brought near the Sanctuary. ${ }^{16}$ He further indicates that certainly sins cannot be carried like a burden, and taken off the shoulder of one being to be laid on that of another being. ${ }^{17}$ For him, this ceremony was of a symbolic character, and served to impress people with a certain notion, and to induce them to repent; "as if to say, we have freed ourselves of our previous deeds, have cast them behind our backs, and removed them from us as far as possible." 18

TK Cheyne agrees with Maimonides that the purpose of the live goat ritual was to provide the primitive folk with a visible act of removal of the sins and of the consequences of those sins (cf. Lev 14:53). However, in addition, Cheyne believes that the second purpose was to do away with the cult of the שעירים ${ }^{19}$ But, as A Pinker notes, one wonders how giving such a prominent role to a demonic Azazel in a major festival would undermine the cult of the שעירים.

Leviticus 16 details the solemn ceremonies and underscores the spiritual significance of the Day of Atonement. It follows naturally after a section of Leviticus that deals with various impurities (of animals, human body, human clothing, and human dwelling) and their purification (Leviticus 11-15). Leviticus 16 concludes with the purification on the Day of Atonement of the sanctuary and the purification of the people from the spiritual impurities of their sins. The two he-goats were a sin-offering (Lev 16:5) for these two purposes.

5 Kiuchi, Purification Offering, 151; Milgrom, Leviticus 1-16, 1009; John E Hartley, Leviticus. WB; Dallas, TX: Word, 1992:220.

16 Moses Maimonides, The Guide to the Perplexed. New York: Dover, 1956:366.

17 Maimonides, Guide to the Perplexed, 366.

18 Maimonides, Guide to the Perplexed, 366.

19 Bernhard Duhm (Das Buch Jesaia [Göttingen: Vandenhoeck and Ruprecht, 1968]) considered Azazel is the leader of the שעירים, a desert-goblin. Thomas K Cheyne considered Azazel the leader of the fallen angels to which Enoch refers. He thinks that the name of this angel has been deliberately changed from עז "out of reverence, to conceal the true derivation of the fallen angel's name" ("The Date and Origin of the Ritual of the Scapegoat," ZAW 15 1895:155). For William F Albright, "The שעירים were naturally rustic divinities, originally goat demons, and evidently included a heterogeneous lot of old pagan divinities, which were still worshipped, or at least venerated, in rustic areas, farthest removed from the influence of militant Yahwism" ("The High Place in Ancient Palestine," Supplements to Vetus Testamentum 4, 1956:245-6). 


\section{The Live Goat Ritual, a Sacrifice?}

Another issue that calls for comment is whether the live goat ritual is a sacrifice or not. In verse 15, the two goats are designated לחטאת, "for a purification offering," which may imply that both goats are חטשאת animals. ${ }^{21}$ For many scholars, it is unacceptable to assume that the live goat functions as a חטאזת in its own right. P Heinisch considers לחטאת imprecise because only one goat serves as an offering. ${ }^{22}$ ES Gerstenberger believes that in verse 5, the stipulation "two male-goats as a sin offering" does not envision the scapegoat rite at all and that the tridents do not count both rites as "sin offering." Rather, he posits that verse 5 refers "to an atonement offering for the congregation according to the usual schema of a sin and burnt offering." ${ }^{23}$ J Porter, referring to verse 9, posits that only one of the hegoats was used as a sin-offering. By this, Porter is suggesting that the live goat ritual cannot be considered as sacrificial. ${ }^{24}$ Similarly, some other scholars consider the live goat to be only a potential before its selection by lots. ${ }^{25}$ This implies that after the selection, the live goat could not become a sacrificial victim. For R de Vaux the ritual is non-sacrificial in the sense that, primarily, the goat is not given over to YHWH as "an irrevocable gift." 26 Elsewhere he attributes the non-sacrificial character of the goat to the fact that it had become impure with the sins of the people and so was disqualified from serving as a holy sacrificial victim. $^{27}$

Some scholars view the live goat as a חטאת Kurtz contends that the two goats form a single חטשאת. He explains that the live goat rite completes the expiatory process begun with the slain goat. ${ }^{28}$ Similarly, SH Kellogg explains that because the two goats are designated a זמט sacrifice to YHWH: the slain goat shows the means of reconciliation with God and the live goat depicts the effect of sacrifice. ${ }^{29}$ Kiuchi agrees that the two goats together form a single חטאת and suggests the live goat ritual is a special form of the burning of the hattat. ${ }^{30}$ Similar to Kiuchi, B Schwartz thinks that the live goat forms the second part of a two-part חטאת That carries away moral faults after their removal from the sanctuary. Unlike Kiuchi, however, he does not equate the live goat ritual with the disposal of the slain goat's carcass. Schwartz proposes that the live goat does not carry impurities, because, unlike sins,

\footnotetext{
21 Cf. Milgrom, Leviticus 1-16, 1009; idem Leviticus 17-22. New York: Doubleday, 2000:1293.

22 Paul Heinisch, Das Buch Leviticus. Die Heilige Schrift des Alten Testamentes 1. Bonn: Hanstein, 1935:74.

23 Erhard S Gerstenberger, Leviticus: A Commentary. Louisville, Kentucky: Westminster John Knox: 1996:219.

24 Joshua R Porter, Leviticus. CBC; Cambridge: Cambridge University Press, 1976:127.

25 Angel Rodríguez, Substitution in the Hebrew Cultus. Berrien Springs, Michigan: Andrews University Press, 1979:113; A Levine, Leviticus. JPS Torah Commentary; Philadelphia: Jewish Publication Society, 1989:101; Frank H Gorman, The Ideology of Ritual: Space, Time and Status in the Priestly Theology, Sheffield: JSOT, 1990:97 and René Péter-Contesse and John Ellington, A Handbook on Leviticus, New York: United Bible Societies, 1990:244.

26 Roland de Vaux, Ancient Israel: Its Life and Institutions. Trans. John McHugh; London: Darton, Longmans \& Todd, 1961:452.

27 Roland de Vaux, Studies in Old Testament Sacrifice. Cardiff: University of Wales Press, 1964:97.

28 Kurtz, Sacrificial Worship, 395-96, 404-407; 410-13.

29 Samuel H Kellogg, The Book of Leviticus. New York: Funk \& Wagnalls, 1900:266-71.

30 Kiuchi, Purification Offering, 149; cf. 148, 159, 163.
} 
impurities are not only removed from the sancta but also wiped out by the purification offering of the slain goat. ${ }^{31}$

Looking at both sides of the argument, we cannot disqualify the live goat from being a sacrifice for the simple reason that the animal is not slaughtered, grain could be used to perform a חטאת without slaughter as well (Lev 5:11-13). It is important to note that in Second Temple times the goat was killed by pushing it over a cliff, certainly to prevent it from returning to territories of human habitation (Yoma 6:6).

There is a fundamental weakness in the idea that the two goats together form one חטאת. If the live goat continues the sacrificial process begun with YHWH's goat, then those who maintain the notion that Azazel is some kind of demon, have a problem, because Lev 17:7 warns against giving sacrifice to demons. Kiuchi's approach is unacceptable for three reasons. First, the notion that the rituals using the two goats form a single purification offering overlooks the closer relationship between YHWH's goat and the bull for the priests, which are combined at the next hierarchal level as a single חטאת complex (Lev 16:25 - singular חטאז) referred to as "purification offering of purgation" (Exod 30:10; Num 29:11). Second, unlike the bird ritual of Lev 14:4-7, 49-53 in which blood from a slain bird is applied to a live bird that is released, in Leviticus 16, there is no contact/interaction between the slain bull or goat and the live goat to indicate that the live goat continues the same process begun with them. ${ }^{32}$ Third, while the slain purification offerings remove impurities and moral faults (Lev 16:16, 19), the live goat removes only moral faults (vv. 21-22). If the live goat ritual completes the disposal process for one or both of the inner-sanctum purification offerings, one wonders why it does not remove the same list of evils. ${ }^{33}$

The weakness of Schwartz's ${ }^{34}$ approach lies in his understanding of verses 16 and 21 . Concerning verse 16, he states that "the wāw must be a simple conjunction, and the text indicates clearly that a double purgation is described: one that removes both impurities and sins." However, regarding verse 21 he explains that only the deliberate offenses among all

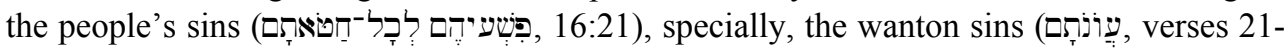
22), are transferred to the scapegoat. He interprets the wāw in when, as in the equivalent syntactic position in verse 16 , it must be a simple conjunction, meaning that the live goat carries off both פשעים and astinct categories. But if

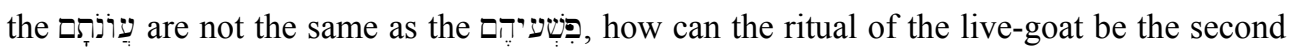
phase of a single ritual that expels from the camp the same evils that were purged from the sanctuary through YHWH's slain goat? Hartley has suggested that the purification offering alone is mentioned to keep the verse short and uncomplicated. ${ }^{35}$ This explanation is unconvincing because there are other verses in the chapter that are more complicated and longer, and we can offer a coherent interpretation for them.

\footnotetext{
31 Baruch Schwartz, "The Bearing of Sin in the Priestly Literature," in Pomegranates and Golden Bells: Studies in Biblical, Jewish, and Near Eastern Ritual, Law, and Literature in Honor of Jacob Milgrom, ed. David Wright, David N Freedman, and Avi Hurvitz. Winona Lake, Indiana: Eisenbrauns, 1995:17-20.

32 Gorman, Ideology of Ritual, 164.

33 Gane, Cult and Character, 256.

34 Schwartz, "The Bearing of Sin in the Priestly Literature," 17-20.

35 Hartley, Leviticus, 236.
} 
In light of the above discussion, I think that there is both continuity and discontinuity between the slain rituals and the ritual of the live goat, which is also called a חטאז The inner-sanctum offerings purge the sanctuary and its sancta of 'impurities,' 'sins,' and 'transgressions' (verse 16), resulting in the purification of the people from 'sin' (verse 30). These three categories of sin are contained and banished by means of the live goat. As D Tidball shows, "the scapegoat would be inadequate but for the dead goat. The acts are mutually complementary." 36 However, if there is a difference, it is best described as Kaiser does: "The one goat makes possible the expiation of the sins laid on it, and thus it is a means of expiating and propitiating Israel's sins, while the other goat exhibits the effects of that expiation." 37 Thus, the people's sin has been both forgiven and forgotten. In effect, the two rites were to assure the people that their sin, whether a ritual transgression or a moral rebellion, consciously done or unconsciously committed and whether previously confessed or unintentionally missed had been forgiven. ${ }^{38}$ On this day cleansing was available for all the sins of Israel (vv. 30, 34); "all bases are covered." 39

We should maintain that each of the two goats, individually, is a goats were meant to effect complete obliteration of transgressions, and were both subjected to the divine decision of the lot. However, it would be too much to consider both as one sinoffering presented to YHWH. The two rituals worked out the desired objective in a different way: the slaughtered goat was a victim intended to atone for sins, while the released goat carried away sins already atoned for. The two goats then represented two aspects of the atonement that God provided. ${ }^{40}$ Both animals taught the Israelites that a sinless agent was removing their sins by vicarious atonement. The goat slain represented the judgment on sin that resulted in death necessary for atonement. The goat sent off into the wilderness with the sinner's guilt imputed to it symbolized the removal of guilt as in Lev 14:4-7. ${ }^{41}$ They implied the acknowledgement of two opposite and opposing forces in the moral world. ${ }^{42}$

Although the live goat is placed "before YHWH," indicating his control over its function $^{43}$ to atone (כפר) (v. 10), it is a unique חטאת because it is not offered to YHWH. Neither its blood nor meat goes to him or his priests. In verse 5, תטאמת should be understood generally to mean "purification ritual," an expression that covers both the purification offering of YHWH's goat and the non-sacrificial ritual with the live goat. The term תט "may have been chosen for its philological sense 'that which removes sin,' which precisely defines the function of the scapegoat.",44

\footnotetext{
36 Derek Tidball, The Message of Leviticus. Leicester, England: InterVarsity Press, 2005:197.

7 Kaiser, "Book of Leviticus," 1111.

38 Tidball, Message of Leviticus, 197.

39 AD Hayes, “Atonement in the Book of Leviticus," Interpretation 52, 1998:13.

40 Marcus M Kalisch, A Historical and Critical Commentary on the Old Testament with a New Translation: Leviticus, vol. 1. London: Longman, 1867-72:209.

41 Lester L Grabbe, “The Scapegoat Tradition: A Study in Early Jewish Interpretation,” JSJ 18, 1987:152-67.

42 Kalisch, Historical and Critical Commentary, 209.

43 George B Gray, Sacrifice in the Old Testament: Its Theory and Practice. Oxford: Clarendon, 1925:317.

44 Milgrom, Leviticus 1-16, 1018. The term "scapegoat" was coined by the translators of the King James Bible because they did not know how to translate the Hebrew term Azazel. The translators understood the $ל$ in לעיזירו (Lev 16:10) in the sense "as a" rather than "to".
} 


\section{Significance of the Rite}

What had been effected in private, between God and Aaron alone, was now made public for all to see. ${ }^{45}$ As G Wenham comments, "the symbolism of this ceremony is transparent." 46 The goat was believed to carry on itself all the sins of the people to a solitary place (v. 22), thus physically removing them from the people and depositing them as far away as possible from the camp, where they could no longer trouble the people. This is reflected in the psalmist's celebration, when he wrote, "as far as the east is from the west, so far has he removed our transgressions from us" (Ps 103:12). The ritual was evocative. Sin was removed from the camp and banished to a barren, uninhabited place. "It is taken to where it belongs, because sin has the effect of turning fertile pastures into desert wastes." ${ }^{47}$ It was a common belief that the desert was the dwelling place of demons and evil powers; perhaps one of them was called Azazel. The person who escorted the goat to the wilderness had to bathe himself and wash his clothes before he could re-enter the camp because of the uncleanness from contact with the goat. The rabbinic writings indicate that whereas at first the goat was left to wander around, in later history the escort, when he had reached his destination, would tie the goat to a rock and then push it from behind over a precipice, where it was torn to pieces before it was halfway down. This was to ensure the complete destruction of the goat and that it would never return to the camp. In later Jewish tradition the arrival of the scapegoat in the desert was communicated all the way back to Jerusalem by the joyful waving of towels (Mishnah, p. 276).

\section{Conclusion}

In this article, I have shown that the two hands used by the high priest over the head could not symbolize the transfer of the ownership of the animal. The transfer here is the moving of the people's sin to the goat. The use of two hands could be to connote quantity of identification. The transfer is the collective sin of all Israel rather than just an individual. In addition, the two hands could be used as representational, one for the high priest and his household and the other for the 'lay' Israelites. I have further demonstrated that the live goat on its own does not atone for the sin of the people, but rather it completes the atonement offered by the slain goat as it takes the atoned sin away. I have also shown that the ritual of the live goat is a unique חטאה חטאת There means 'purification ritual' which expresses the slain goat ritual and the non-slain goat. I have finally indicated that the ritual symbolized the complete eradication of evil from human community.

\footnotetext{
45 Alec Motyer, Look to the Rock. Leicester: InterVarsity Press, 1996:54.

46 Gordon J Wenham, The Book of Leviticus. London: Hodder and Stoughton, 1979:233.

47 Tidball, Message of Leviticus, 196.
} 


\section{BIBLIOGRAPHY}

Albright, William F 1956. "The High Place in Ancient Palestine." Supplements to Vetus Testamentum 4:242-58.

Cheyne, Thomas K 1895. "The Date and Origin of the Ritual of the Scapegoat."

Zeitschrift für die alttestamentliche Wissenschaft 15:153-156.

Duhm, Bernhard 1968. Das Buch Jesaia. Göttingen: Vandenhoeck and Ruprecht.

Feder, Yitzhaq 2011. Blood Expiation in Hittite and Biblical Ritual: Origins, Context and Meaning. Atlanta: Society of Biblical Literature.

Gane, Ray 2005. Cult and Character: Purification Offerings, Day of Atonement, and Theodicy. Winona Lake, Indiana: Eisenbrauns.

Gerstenberger, Erhard S 1996. Leviticus: A Commentary. Louisville, Kentucky:

Westminster John Knox.

Gese, Hartmut 1981. Essays on Biblical Theology. Translated by Keith Crim. Minneapolis: Augsburg.

Ginsburg, Christian D 1961. Leviticus. Grand Rapids: Zondervan.

Gorman, Frank H 1990. The Ideology of Ritual: Space, Time and Status in the Priestly Theology. Sheffield: JSOT.

Grabbe, Lester L 1987. "The Scapegoat Tradition: A Study in Early Jewish Interpretation." Journal for the Study of Judaism 18:152-67.

Gray, George B 1925. Sacrifice in the Old Testament: Its Theory and Practice.

Oxford: Clarendon.

Hartley, John E 1992. Leviticus. Word Bible Commentary. Dallas, TX: Word.

Hayes, John H 1998. "Atonement in the Book of Leviticus.” Interpretation 52:5-15.

Heinisch, Paul 1935. Das Buch Leviticus. Die Heilige Schrift des Alten Testamentes 1. Bonn: Hanstein.

Helm, Robert 1994. “Azazel in Early Jewish Tradition.” Andrews University Seminary Studies 32:217-226.

Kaiser, Walter C 1994. “The Book of Leviticus.” Pages 983-1191 in vol. 1 of The New Interpreter's Bible. Nashville, TN: Abingdon.

Kalisch, Marcus M 1867. A Historical and Critical Commentary on the Old Testament: with a New Translation, Leviticus. London: Longmans.

Kellogg, Samuel H 1900. The Book of Leviticus. New York: Funk \& Wagnalls.

Kiuchi, Nobuyoshi 1987. The Purification Offering in the Priestly Literature: Its Meaning and Function. Journal of the Study of the Old Testament Supplement 56. Sheffield: JSOT Press.

Kurtz, Johann H 1980. Sacrificial Worship of the Old Testament. Translated by James Martin. Minneapolis: Klock \& Klock.

Levine, Baruch A 1989. Leviticus. JPS Torah Commentary. Philadelphia: Jewish Publication Society.

Maimonides, Moses 1956. The Guide to the Perplexed. New York: Dover.

Milgrom, Jacob 1976. "Sacrifices and Offerings, OT." Pages 763-771 in The Interpreter's Dictionary of the Bible Supplementary Volume. Nashville: Abingdon Press. 
1991. Leviticus 1-16. Anchor Bible 3. New York: Doubleday. 2000. Leviticus 17-22. Anchor Bible 3A. New York: Doubleday.

Motyer, Alec 1996. Look to the Rock. Leicester: InterVarsity Press.

Nihan, Christophe 2005. "From Priestly Torah to Pentateuch: A Study in the Composition of the Book of Leviticus." DTh diss., University of Lausanne.

Péter-Contesse, René and John Ellington 1990. A Handbook on Leviticus. New York: United Bible Societies.

Pinker, Aron 2007. "A Goat to Go to Azazel," Journal of Hebrew Scriptures 7:1-25.

Porter, Joshua R 1976. Leviticus. Cambridge Bible Commentary. Cambridge: Cambridge University Press.

Rodríguez, Angel M 1979. Substitution in the Hebrew Cultus. Berrien Springs, Michigan: Andrews University Press.

Schwartz, Baruch J 1995. "The Bearing of Sin in the Priestly Literature." Pages 3-21 in Pomegranates and Golden Bells: Studies in Biblical, Jewish, and Near Eastern Ritual, Law, and Literature in Honor of Jacob Milgrom, edited by David Wright, David N Freedman, and Avi Hurvitz. Winona Lake, Indiana: Eisenbrauns.

Snaith, Norman H 1967. Leviticus and Numbers. New ed. London: Nelson.

Tidball, Derek 2005. The Message of Leviticus. Leicester, England: InterVarsity Press.

Vaux, De Roland 1961. Ancient Israel: Its Life and Institutions. Translated by John McHugh. London: Darton, Longmans \& Todd. 1964. Studies in Old Testament Sacrifice. Cardiff: University of Wales Press.

Weinfeld, Moshe 2004. The Place of the Law in the Religion of Ancient Israel. Leiden: Brill.

Wellhausen, Julius 1994. Prolegomena to the History of Israel. Atlanta: Scholars Press. Wenham, Gordon J 1979. The Book of Leviticus. London: Hodder and Stoughton.

Zohar, Noam 1988. "Repentance and Purification: The Significance and Semantics of in the Pentateuch." Journal of Biblical Literature 107:609-618. 